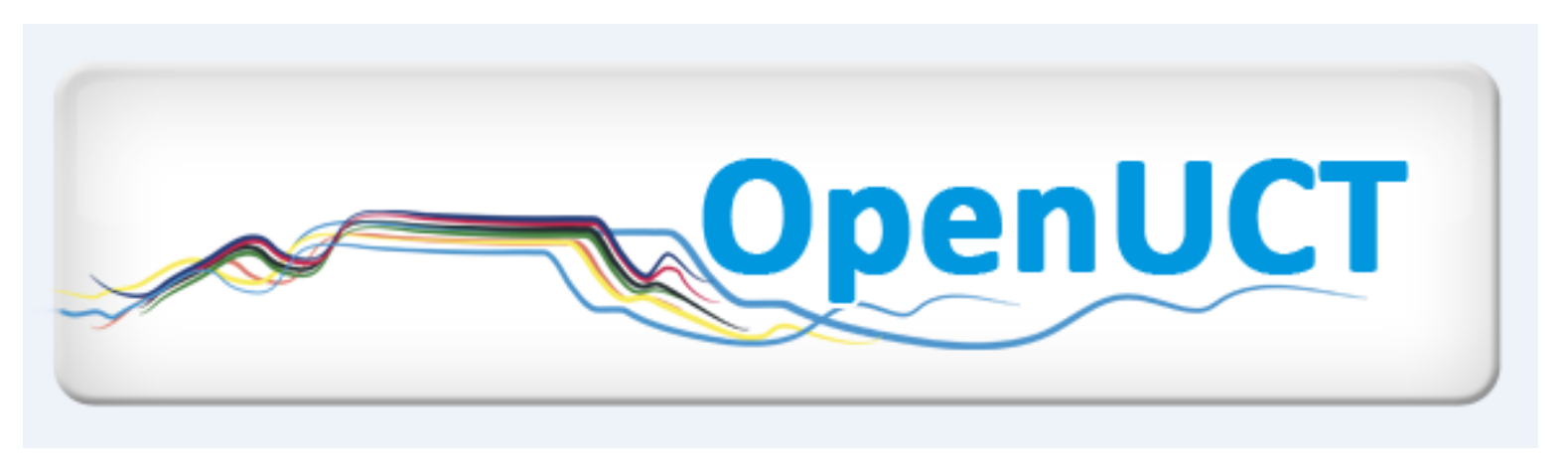

This is the post-print of Jawitz, J. 2012. Race and assessment practice in South Africa: understanding black academic experience. Race Ethnicity and Education. 15(4): 545-559. DOI: 10.1080/13613324.2011.645568.

It is made available according to the terms of agreement between the author and the journal, and in accordance with UCT's open access policy available:

http://www.openuct.uct.ac.za/sites/default/files/UCTOpenAccessPolicy.pdf, for the purposes of research, teaching and private study. 


\title{
Race and assessment practice in South Africa: understanding black academic experience
}

\author{
Jeff Jawitz \\ Centre for Higher Education Development, University of Cape Town, South Africa
}

\begin{abstract}
Despite efforts to transform the racialised system of higher education in South Africa inherited from apartheid, there has been little research published that interrogates the relationship between race and the experience of academic staff within the South African higher education environment. Drawing on critical discourse analysis and critical race theory, this article traces the experience of two black male academics in relation to the assessment practices of their colleagues at a historically white university in South Africa. The interviewees, both graduates from the departments in which they teach, reflected on their experience of their departmental assessment practices both as black students and black academics. The analysis concludes that despite their differing perceptions and experiences they both regard the assessment practices of some of their white colleagues as undermining of their black students' efforts to succeed.
\end{abstract}

Keywords: discourse analysis; race; assessment; academic; transformation

\section{Introduction}

Since 1994 the South African government has embarked on a drive to transform the racially segregated higher education system, primarily designed to serve the minority white community, into a resource for all South Africans. Transformation initiatives have included desegregating institutions through implementing affirmative action and employment equity policies aimed at reconstituting the racial composition of the student and staff bodies to reflect the racial profile of the general population.

Despite the dismantling of the system of racial legislation in South Africa, most South Africans continue to use racial categories in multiple ways. Firstly, the implementation of the initiatives listed above has necessitated engagement with race and the use of a transformation discourse in planning and administration which includes the use of racial descriptors. Secondly, racial descriptors continue to be used in everyday life to talk about and make sense of people's lives (Posel 2001; Seekings 2008). 
Thirdly, and in contrast to the above, there appears to be a discourse of silence that surrounds race with respect to research into student learning and academic practice. This silence is evident in articles published in the primary journal for higher education research in South Africa, the South Africa Journal of Higher Education, where from 2004 to 2009, with a few exceptions (Erasmus 2006; Esakov 2009; Portnoi 2009; Soudien 2008), there has been a lack of engagement with the concept of race in relation to higher education development.

This multiple use (and non-use) of race represents a serious challenge to anyone wishing to understand the possibilities and obstacles underlying higher education development in South Africa. Several important studies have been published elsewhere (Robus and Macleod 2006; Walker 2005), but work presented at the key forum in South Africa for discussing teaching and learning in higher education, the annual conference of the Higher Education Learning and Teaching Association of Southern Africa (HELTASA) has not reflected a serious engagement with race. Between 2007-2009, the HELTASA conference programme included only three presentations that explicitly focused on issues of race, two of them by this author. One can speculate as to the reasons for this silence, including methodological challenges, political sensitivities, a need to maintain 'cultural safety' (Tolich 2002), the belief that race does not matter, or the desire to avoid reinforcing South African exceptionalism to be able to publish work internationally.

It was the realization of my complicity in this silence that gave rise to this article. Between 2004 and 2007, I undertook a major study at a historically white South African university into how academics learn to judge student performance in complex assessment tasks (Jawitz 2009a). In this study I chose not to address the ways in which race might intersect with assessment practice despite the research being conducted in the highly racialised context of South Africa. This decision was made primarily as I felt inadequately equipped to embark on this line of research. In describing their experience of assessment practice in their departments, only two of the 31 academics interviewed, both new black male academics, spoke of a relationship between race and the assessment practices of their colleagues. While I chose to bracket out race in this larger study, these two interviews continued to unsettle me. It began to feel as if my research choices as a white male academic, in concert with the choices of other white male colleagues, who form the majority of research active academics in South Africa (Council on Higher Education 2009), were serving to silence both black, and white academics' experience of race in their work. This discomfort provoked me to begin reading in the area of critical race studies. As a result I decided to revisit these two interviews and face the challenge of incorporating race into my analysis of academic practice.

The absence of a detailed analysis of race in higher education is not peculiar to South African research. Critical race theorists critique the 'colour-blindness' 
evident in most analyses of education as a fundamental problem arising out of a liberal discourse which accepts the notion of whiteness as normal and being 'not white' as abnormal (Dixson and Rousseau 2005, 16). Given the political nature of research

into racism it is not surprising that this work has generated 'heated methodological debates' in academic journals elsewhere (Connolly 1998). Some argue that research into racism should not only identify forms of inequality but should also challenge such social injustice (Troyna and Carrington 1993). There are also the challenges presented by the unintended consequences of such research. There is always the danger that such research might strengthen 'certain stereotypes and ideologies that further marginalize or pathologize' black students and staff (Gillborn 1998). The challenge for any researchers is how to avoid reinforcing these racial stereotypes.

\section{The South African university as a racialised space}

The dominant albeit controversial means of describing similarity and difference in the South African context is through the use of the racial constructs 'black' and 'white.' The term 'black' has a complex history in South Africa which has left it with multiple meanings. In the vocabulary of transformation the term 'black people' refers to persons who in apartheid South Africa were excluded from the political process, namely, those previously classified Coloured, Indian or African (Department of Labour 1998) and this is how I have chosen to use the term. I also use the term 'white' to refer to those persons who would previously have been classified as such.

While it is accepted that during apartheid 'intellectual discourse, teaching and learning, curriculum and texts, and knowledge production and research were strongly affected by the racist, patriarchal and authoritarian apartheid social order' (Badat 2009, 457), South African higher education continues to be a highly racialised space. Jansen (2009) refers to the challenges of teaching within 'postconflict societies' such as South Africa, where classrooms are 'deeply divided places where contending histories and rival lived experiences come. . .into the same pedagogical space' (208). Robus and MacLeod (2006) show in their research of a South African university how 'higher education institutions are racialised through the intricate interweaving of macro-level processes and discourses that recur in everyday talk and practice' $(2006,463)$.

The experience of this racialised space is reinforced by the contested practice of requiring student and staff applicants to universities in South Africa to self-classify themselves racially. This practice is justified in order to facilitate the implementation of admissions and employment equity policies that seek to address historical imbalances in enrolments and employment practices. While the implementation of affirmative action strategies in admissions has seen student enrolment demographics change significantly during the past 20 years, employment equity policies have had minimal effect as 'white staff continue to fill 
most of the academic posts at all levels' (Council on Higher Education 2009, 75).

\section{Researching race in higher education}

In seeking to re-analyse the two interviews I chose to explore the use of critical race theory and critical discourse analysis. Critical race theory (CRT), which draws strongly on narrative analysis, has only recently been applied to help understand the ways in which race shapes discourses, social structures and academic practices in higher education (Walker 2005; Yosso 2005). Critical race theorists argue that racism is so embedded in society that it has become accepted as natural and researchers have an obligation to challenge the ideology that maintains white privilege (Yosso 2005, 74). Through the construct of 'voice,' acknowledging the experience of black men and women, CRT seeks to draw out the 'counterstories' that challenge the dominant stories that reproduce white power while appearing to promote equality. It also seeks to reveal racism at both the level of 'micro aggressions' between individuals and at the macro-level in the form of institutional racism (Dixson and Rousseau 2005).

I view critical race theory as an important tool with which to try and unravel the 'continued hold race has on our lives' (Erasmus 2010, 397), particularly the hold it has on academic practices in South African universities. Critical race theory demands a listening for 'the changing, disguised, use of race' rather than just using race as an analytical category and provides a way of working with race in South Africa as a social construct while at the same time constructing knowledge and promoting practice aimed at 'its demise' (Erasmus 2010).

Research interviews involve working with personal narratives and take place in the context of discourses constructing and being constructed by what is being said (Kvale 1996). By discourse I am referring to the use of language as a 'form of social practice' to engage in both 'representation' and 'action' (Fairclough 1992). Critical discourse analysis can be viewed as a method that reveals how individuals shape the discourses they operate within, and what they do, not only in response to dominant discourses, but as part of their agency in creating opportunities for themselves (Pennycook 1994). It enables one to bring together the social and discursive practices surrounding the text with the discourses evident within the text itself (Fairclough 1992). A key question posed through discourse analysis is, 'why, at a given time, out of all the possible things that could be said, only certain things were said' (Ball 1990, cited in Pennycook 1994, 116)?

\section{Researching black academic experience}

All research in South Africa takes place in the context of a country coming to terms with the challenges of building a society based on equality and 
social justice. I am researching a field of which I am a member. As a middle-aged white male academic I occupy a position in South African society that is associated with past and present privilege. As academics in South Africa we are challenged to undertake research that contributes meaningfully towards ending the glaring social inequalities without reinforcing the racial stereotypes that underpinned the previous apartheid order. A commitment to this challenge forms part of my research habitus and serves to filter my research gaze.

In the major study referred to above, I had spent approximately six months in each of three departments at the same university exploring complex assessment practice. I had interviewed the majority of academics in each department and asked them to talk about their experience of being new in the department and learning what was expected in the assessment of complex student performance. I regard the research interview as a narrative co-constructed by both interviewer and interviewee rather than a means for the interviewer to access an 'objective social reality' of the person being interviewed (Kvale 1996, 159). I used pre-deter-mined questions to initiate the interviews, and then allowed interviewees to expand based on their own experience, at times steering the conversation in the direction that I felt was relevant for my research. The discursive practice in the interviews was largely shaped by a research discourse with its limitations on the role of the interviewer and commitment to interviewee confidentiality and anonymity. Names of individuals, departments and the institution have been changed to protect the identities of the participants.

The two black interviewees who spoke freely about their racialised experiences, Joe and Zaid, were of similar age and cultural background. They were both graduates of their departments and had been teaching as academics for approximately a year. I had met them on separate occasions before this research project, one in a social setting or the other at a staff development workshop. I had also previously met several of the other academics interviewed in their departments.

Zaid worked in the Department of Design, where black academics made up $40 \%$ of the full-time academic staff and included the head of department. There were also a large number of black part-time professionals who taught and examined within the department (Jawitz 2009b). All of the full-time black academic staff in this department were interviewed, but Zaid was the only one who referred to race in his discussion of assessment practice. In contrast, Joe was the only black academic in the Department of Natural Sciences at the time of the study (Jawitz 2008).

I revisited Joe and Zaid's interview transcripts with the aim of incorporating race into my analysis of their stories. The texts I selected for examination are extracts from these interview transcripts. 


\section{Talking 'black' and 'white'}

Both Joe and Zaid use the word 'black' with reference to academics and students in ways that suggest a comfortableness with their black identities. Joe remarks that 'as black academics we're more sensitive to them [black students]' and that 'as a black academic I think that there is pressure on me,' while Zaid refers to the 'two black assessors' and the 'soft handling of black students.'

In contrast they differ substantially in their use of the construct 'white.' Joe never uses the phrase 'white academic.' At times it is clear that he uses the word 'academic' to refer to all academics such as in the reference to the tearoom where 'academics. . . sit together by themselves.' However when Joe asks 'Was the interpretation of the academic. . . when the [black] student went to him, a racist one?' I get a strong sense that he is talking about a white academic. One explanation might be that as the only black academic in the department Joe feels it is unnecessary to qualify the term 'academic.' However his unwillingness to ascribe a racial identity to his colleagues, could serve to reinforce the normalization of whiteness in the notion of the academic.

In contrast, Zaid, uses the descriptor 'white' in reference to his colleagues in several places. He remarks that 'some white people would be marking high,' and that 'the majority of the other assessors who were white, passed him' or that 'white staff would be. . .more kind.' Through his use of the terms 'black' and 'white' Zaid indicates his acceptance of their value in describing academic practice in his department. They provide him with the tools to explain the experience that leads him to conclude that race is integrally tied up with academic practice.

\section{Case 1: grappling with black student discourse}

The first discursive event I analyse is an extract from the second of two hour-long interviews with Joe. I had come to what I thought was the end of the interview and had switched off the tape recorder. However Joe continued to talk about his experiences as a black academic, so, with his permission, I switched the tape recorder on again.

In this section of the data I noticed that he seemed to use the interview to work through his discomfort with the fact that his black students viewed some of his colleagues as racist. The central issue appears to be black students' perceptions of unfairness in the assessment of their work.

Just in this week we have had the whole thing about race come up. How students feel that certain people are racist and it's a race issue here in this department. Certain white students get away with the minimal amount of work while, you know, [black students] have to like do a hundred things. . .they're interpreting that as racism. 
Joe reports that his black students believe that white students get preferential treatment and that some black academics have in the past gone along with this practice.

The student says, 'some of the so-called black academics are just coconuts.' 1 . . . He mentioned they like lick you-know-what. And they mentioned the [black] supervisor who was here before [me].

Joe recalls how as a student in the same department he had also held the view that the academics discriminated against black students.

We put a lot of effort into our Honours write up and we got less marks than the white students, you know, and then we felt that it was unfair.

However twice during the course of the interview he comments on how his perspective had changed since his appointment as an academic, and how 'looking back' he realises that 'it may not have been a race question it may just have been that our English was bad.' These statements represent a break with his student past and an assertion of his emerging identity as an academic. They reflect Joe's transition from the world of the black student to the world of the academic.

I have realized now in this position that things are different, that, you know, there are other pressures on academics which students are unaware of.

But the transition is tentative. The use of the word 'maybe' in several places in the interview reveals a hesitancy to commit.

... maybe it is to do with race in a sense that maybe you are more comfortable with a person that you feel is from your same background.

... and maybe, I wonder if other, I must actually ask the other academics, black academics. . .

Further evidence of Joe's exploration of positions in opposition to the black student discourse is provided by his drawing on the rational scientific discourse, associated with his professional training in his use of the words such as 'valid' and 'proof.' He wonders whether 'the perception [of racism is] valid or not. . .I don't even know whether it's valid or not' and shortly thereafter he questions whether students have 'proof' of their claims. However he acknowledges that it is 'the way students interpret it' that is the 'big thing.'

Joe's sympathy with the black students' position is fuelled by his own recent experience. In a different part of the interview he describes how he had confidently passed an assignment submitted by a black student he was supervising using a set of assessment criteria he had developed in discussion with a colleague, Jane. However the same assignment had been failed by the 
two other markers, both white colleagues. He struggled with how to respond to this. He wished to get feedback on how to improve his assessment practice but felt fearful of approaching the other markers and never did so.

How would she perceive me coming to her. . .as a new academic?... . Would she take it to mean: 'You know you're actually criticizing my assessment and you're criticizing, you know, me?'

Here he puts forward his identity as a new academic as underlying his fear of approaching the other assessors, but this happens in a context where he is also the only black academic in the department aware of black students' perception that they are assessed unfairly by his white colleagues.

Fairclough argues that 'discourses in Foucault's sense generate ideological positions, through "systems of rules which make it possible for certain statements but not others to occur at particular times, places and institutional locations"' (Fairclough 1992, 40). Joe's inability to talk about race in the department suggests the existence of a powerful discourse (there may be more than one) that makes little room for discussion of issues of race within the department. The remaining academic staff interviewed from this department made no reference to the issues raised above by Joe.

Bakhtin's notion of intertextuality is helpful in identifying elements of other texts within the text under investigation (Fairclough 1992, 84). In this case there is evidence of manifest intertextuality arising out of Joe's use of direct quotes as a feature of his conversational style. He uses the interview to relate what students have told him and his use of direct speech serves to make me feel I am a 'witness' to what was said.

- this one person told me, 'No, this person is racist' and he has proof of it. . .

- this guy told me, 'Yes, because the white student's English was so good he got full marks. . . while my English wasn't that good.'

- the student says 'some of the so-called black academics are just coconuts.'

- the person said 'the white students. . it was easy, they got their masters, we did everything.'

These 'quotes' from black students serve to bring the black student voice into the text. Joe is using the black student discourse with which he is familiar, having previously been a student in the department, to communicate his perception of the practice in the department.

The interview suggests the existence of a counter discourse in the department amongst black students and Joe, the sole black academic. This discourse is confined to his own laboratory-based 'tea room' where he and his students choose to have their tea. Joe feels that it is unlikely that the issues discussed between himself and his students 'will be brought up upstairs' in the 
departmental tearoom. He also speculates that students feel 'more comfortable' to talk to him more openly because he is 'from the same background.'

... it could be subconsciously race and background - that you are from the same group.

He has not shared what black students have told him with his colleagues, with the exception of Jane, a fellow newcomer in the department. He justifies this by saying that students have taken him into their confidence, however he also acknowledges that 'you can't really broach [these issues] with the academics' in the department. His inability to talk about issues of race with his colleagues in the department, only further serves to reinforce his identity as a black academic and to make him want to seek out the advice and support of other black academics. At this point he reveals the existence of a black academic discourse within the university.

I must actually ask other academics, black academics. . . whether they find that the black students kind of rely on them or see them as a voice on their behalf and does that put pressure on them. ... I didn't ask for that role, you know.

His willingness to discuss issues of race with me, a white researcher-academic in the interview, contrasts starkly with his unwillingness to discuss it with his colleagues. One way of interpreting why he is sharing this information with me is that he trusts me and trusts that I will not reveal what he has said to anyone. This feels like a weak interpretation as he knows that a research project aims to reveal what has been said, albeit it under conditions of anonymity. An alternative interpretation is that he is using me and my research project to project both his own voice as a black academic and the black student voice. So he is producing a text that explicitly captures elements of the black student discourse.

The text also reveals evidence of a staff development discourse arising from the fact that we had previously met at an academic staff development workshop. Joe views me as more than a researcher given his experience of me in that context. Our experience of the workshop forms part of the 'members resources' (Fairclough 1992, 72) that both Joe and I draw on in the production of this text. He expresses the view that all of his colleagues in the department should participate in such workshops and by doing so he is pursuing this agenda through the interview in the hope that I will take this suggestion on board in my broader staff development role.

The influence of the discourse of excellence is also evident in Joe's justification for not wanting to intervene on behalf of black students. He argues that '[the student], I think, will appreciate if he is judged according to his talents and not because his supervisor has spoken out for him.' Towards the end of the extract he spends some time justifying this position. It clearly places him at risk 
of taking a position in opposition to the black student discourse and siding with the dominant white academic discourse, a strategy that could result in him being labelled a 'coconut.'

The above analysis lays the ground for attempting to identify the particular configuration of discourses that make up the order of discourse characteristic of the context that has given rise to this text. Fairclough uses orders of discourse to refer to the 'totality of discursive practices within an institution or society and the relationships between them' $(1992,43)$.

Two sets of discourses appear to exist in opposition to each other within the prevailing order of discourse. There is a discourse of excellence clustered with the white student and academic discourse, and supported by a rational scientific discourse associated with the discipline. On the other hand there is a discourse of equity made up of the black academic and black student discourses. Joe's inability to talk about issues of race with his colleagues in the department suggest that the former cluster is dominant within the department, forcing alternative avenues for expression to be found such as through alternative tea rooms, networking with black academics across departments, and within the spaces created by academic staff development workshops. Not only does Joe appear to be making use of these alternative avenues, but an indication of the agency he is exerting is his use of my research and the interview itself as a vehicle to give voice to the non-dominant cluster of discourses.

However the discourse of equity has support outside of the department from societal formations at both the institutional and the national level (Hall 2008). This would suggest an element of instability with respect to the order of discourse as revealed in this text. If the national and institutional initiatives to change the profile of academic staff were to succeed and Joe were to be joined in his department by significant numbers of black academics, this might result in significant shifts in this order of discourse with the possibility of the order of dominance being reversed.

\section{Case 2: 'a soft handling of black students'}

In my hour-long interview with Zaid, the first reference to race and assessment practice in the Department of Design came very near the start of the interview. He had had his first experience of assessing complex student performance the previous year and referred to an incident involving the assessment of final year students by a panel of assessors in which 'issues of race comes into play.'

[T] here was one particular case where a [black] student, in my opinion, his work wasn't of a standard that should be passed and we were two black assessors on the panel, me being internal and the other black person being an external examiner, and both of us failed him. ... In the after-exam caucus. . one person did feel that she would have failed him except that he 
needed to get through. ... I think it demonstrates that there are issues beyond the pure kind of piece of work that's presented. . .. that have an influence, to what extent I don't know.

In this extract Zaid asserts his identity and that of his external examiner colleague as black academics and raises his concern about the influence of race on assessment practice. However the role of race is not clarified and he does not expand on this issue at this point in the interview. Later in the interview I asked whether he could recall any critical incidents in his learning how to assess student performance.

\begin{abstract}
There haven't been critical incidents, it's been more of maybe my own sort of interpretation of certain environments, especially with design work where I thought that, I wonder if it was a white student whether the. . .work would have been interrogated more. . .. I think maybe there's a kind of soft handling of black students. . .by white staff.
\end{abstract}

At this stage Zaid is tentative, and stresses that his perception that there is 'soft handling' of black students by white staff is based on his own 'interpretation of certain environments.' As with Joe, Zaid refers to his experience as a student in the same department. He describes his experience of being taught by Roger, a black academic and current head of department.

He was tough. He wasn't kind of shy to kind of criticize heavily and I took it because it helped me. Other black students felt that they were kind of victimized and white staff would be kind of more kind. [Zaid]

He does not identify with the experience of black students in the way that Joe does. He distances himself from his former black student peers by rejecting their sense of being 'victimized' by Roger for being black, and instead voices approval of Roger's 'tough' approach.

His use of the words 'soft' and 'kind' in relation to the behaviour of the white academics towards black students suggests that he views this behaviour as paternalistic towards black students. In contrast his description of Roger's behaviour as 'tough' and '[not] shy to. . .criticize' suggests an approach that demands the high standards of students that are associated with academic success.

Returning to the incident involving the panel of assessors, Zaid explains that he had sided with the black external examiner in opposing what they perceived to be a tendency amongst his white colleagues to mark black students more leniently than white students.

The black [external examiner] deliberately marked very low because in his opinion he knew some white people would be marking high and he wanted to. . .mark low because he wanted the average to be a fail because he believed that the student wasn't of a quality or a standard that should pass. 
He related how afterwards he and the external examiner had raised their concerns with the rest of the panel and there had been a frank discussion during which some of his white colleagues had admitted to adopting a more lenient approach to students from 'disadvantaged backgrounds.' Zaid attempts to explain this behaviour by describing how, given South Africa's particular history, assessment practice occurs within a 'sensitive climate' in which some of his white colleagues do not want to appear to be 'prejudiced against a black person,' and this influences how they judge the performance of black students.

I think it's part of the sensitive kind of climate that we find ourselves in. ... I think it's a general thing, how you kind of treat black people, a sensitivity, kind of not coming across as prejudiced against a black person.

Zaid and the black external examiner disapproved of this practice.

His opinion and his position, which I shared, was that we can't kind of, as part of black, I wouldn't say consciousness, but black responsibility. . . say it's okay if it's not okay, to black students or. . .to anybody. [Zaid]

Zaid acknowledges there was a willingness to engage with these issues within the department and that his colleagues were open to discussions of this kind. In confronting his white colleagues he had asserted his identity as a black academic in the South African context in a way that Joe had not been able to do in his department. He argues that this experience had reinforced his view that it was important to have a 'representative' examining and teaching body making judgements on student performance. His comments support one of the central features of the transformation agenda for higher education in South Africa, namely the need to ensure that the academic staff body at higher education institutions reflects the racial, gender and disability profile of the South African population as a whole.

\section{Discussion}

The data from the two case studies highlight the complex nature of perceptions of race and its relationship with academic practice. Critical discourse analysis has helped to highlight the way in which the interview data is 'saturated' with discourses based on race. Zaid's experience of working with colleagues as part of an assessment panel provides a vivid example of how the 'contending histories and rival lived experiences' engage within 'the same pedagogical space' (Jansen 2009) and impact on the academic practice within a department.

The data also serves to breakdown the notion that black academic staff share the same experiences of academic practice within the racialised space of higher education. In this way it helps to undermine the kinds of stereotypes 
that Gillborn (1998) warns about. Zaid's account of how his fellow black students preferred what they perceived to be the 'soft' or 'kind' approach of white lecturers towards them stands in stark contrast to Joe's account of his own and his black students' experience of assessment practices of white academics who marked them more harshly than their white student counterparts.

From a critical race theory perspective the two case studies reflect two contrasting versions of a conspiracy (Gillborn 2008). As a student and academic member of staff in the Department of Natural Science, Joe's experience represents one position, namely that white lecturers mark black students more severely than white students and therefore in the short term they are perceived to be standing in the way of their success. Zaid's experience as student and academic in the Department of Design represented a second position, namely that white lecturers are seen to be marking black students more leniently than white students and thereby in the long term undermining their chances of success. Despite these differing experiences and interpretations of the academic practice they observe, both of these positions support a single notion that the behaviours of their white academic colleagues serve to reinforce inequality. They feed into black student and staff perceptions that black students' efforts to succeed are undermined by the assessment practices of white academics.

\section{Conclusion}

From my analysis of these two interviews I argue that academic practices in higher education in South Africa cannot be fully understood without taking race into account. In complementary ways critical discourse analysis and critical race theory have helped to bring to the fore some of the problems that both black and white academics need to acknowledge and address in their coming to terms with the challenge of transforming academic and institutional practices in higher education in South Africa. Substantial research needs to be undertaken to understand how social factors such as race, gender and class impact on academic practice and serve to undermine efforts to develop a higher education system in South Africa that is inclusive and equitable in its dealings with students.

While these two interviews have helped to probe the experiences of two new black academics, they have not helped to explain the silence that surrounds race within research into academic practice. This silence about race, evident in the remaining interviews of my study, represents a serious challenge to anyone wishing to understand the possibilities and obstacles underlying academic development in general and academic staff development in higher education in South Africa.

The findings of this study has had a profound influence on the future direction of my research and academic staff development work and challenges 
my role as a white academic actively pursuing the transformation agenda. It points to the need to explore the potential effect of 'colour-blindness' on the academic practices of, in particular, my white academic colleagues. It also highlights the significance of an emerging black academic identity within the South African higher education context that is looking for space to articulate its concerns in relation to dominant academic practices, particularly at historically white institutions. Further research is needed to understand how contesting discourses both work against and open up opportunities for transformatory action and how different expressions of identity, especially identity in relation to race, serve to impact on academic practice, and the experience of academics and student in the highly racialised context of South African higher education.

\section{Note}

1. A coconut is black outside and white inside and is used in South Africa as a derogatory term to refer to a black person taking on aspects of white lifestyle and values and who may also be seen to be serving the interests of white people. The term 'Oreo' is used in a similar way in the USA.

\section{References}

Badat, S. 2009. Theorising and analysing institutional change in SA higher education. Studies in Higher Education 34, no. 4: 455-68.

Ball, S. 1990. Politics and policy making in education. London: Routledge.

Connolly, P. 1998. Introduction. In Researching racism in education: Politics, theory and practice, ed. P. Connolly and B. Troyna, 1-11. Buckingham: Open University Press.

Council on Higher Education. 2009. The state of higher education in South Africa. Higher Education Monitor No. 8. Council on Higher Education.

Department of Labour. 1998. Employment Equity Act, Government Gazette no 19370, 19 October, Pretoria.

Dixson, A.E., and C.K. Rousseau. 2005. And we are still not saved: Critical race theory in education ten years later. Race Ethnicity and Education 8, no. 1: 7-27.

Erasmus, Z. 2006. Living the future now: 'Race' and challenges of transformation in higher education. South African Journal of Higher Education 20, no. 3: 413-25.

Erasmus, Z. 2010. Contact theory: Too timid for "race" and racism. Journal of Social Issues 66, no. 2: $387-400$.

Esakov, H.-J. 2009. Reading race: The curriculum as a site of transformation. South African Journal of Higher Education 23, no. 1: 69-82.

Fairclough, N. 1992. Discourse and social change. Cambridge: Polity Press.

Gillborn, D. 1998. Racism and the politics of qualitative research: Learning from controversy and critique. In Researching racism in education: Politics, theory and practice, ed. P. Connolly and B. Troyna, 34-54. Buckingham: Open University Press.

Gillborn, D. 2008. Coincidence or conspiracy? Whiteness, policy and the persistence of the black/white achievement gap. Educational Review 60, no. 3: 229-48.

Hall, M. 2008. The objects of transformation in higher education. Social Dynamics 34, no. 1: 74-85.

Jansen, J.D. 2009. Knowledge in the blood: Confronting race and the apartheid past. Cape Town: UCT Press and Stanford University Press.

Jawitz, J. 2008. Learning to assess in the academic workplace: Case study in the Natural Sciences. South African Journal of Higher Education 22, no. 5: 1006-18. 
Jawitz, J. 2009a. Learning in the academic workplace: The harmonization of the collective and the individual habitus. Studies in Higher Education 34, no. 6: 601-14.

Jawitz, J. 2009b. Academic identities and communities of practice in a professional discipline. Teaching in Higher Education 14, no. 30: 241-51.

Kvale, S. 1996. Interviews: An introduction to qualitative research interviewing. Thousand Oaks, CA: Sage.

Pennycook, A. 1994. Incommensurable discourses? Applied Linguistics 15, no. 2: 115-38.

Portnoi, L. 2009. Transformative change? Institutional formalities and institutional realities. South African Journal of Higher Education 23, no. 2: 373-85.

Posel, D. 2001. What's in a name? Racial categorizations under apartheid and their afterlife. Transformations: Critical perspectives on Southern Africa 47: 50-74.

Robus, D., and C. Macleod. 2006. 'White excellence and black failure': The reproduction of racialised higher education in everyday talk. South African Journal of Psychology 36, no. 3: 463-80.

Seekings, J. 2008. The continuing salience of race: Discrimination and diversity in South Africa. Journal of Contemporary African Studies 26, no. 1: 1-25.

Soudien, C. 2008. The intersection of race and class in the South African university: Student experiences. South African Journal of Higher Education 22, no. 3: 662-78.

Tolich, M. 2002. Pākehā "paralysis": Cultural safety for those researching the general population of Aotearoa. Social Policy Journal of New Zealand 19: 164-78.

Troyna, B., and B. Carrington. 1993. 'Whose side are we on?' Ethical dilemmas in research on 'race' and education. Critical introduction: Researching racism and education. In Racism and education, ed. B. Troyna, 104-16. Buckingham: Open University Press.

Walker, M. 2005. Rainbow nation or new racism? Theorizing race and identity formation in South African higher education. Race Ethnicity and Education 8, no. 2: 129-46.

Yosso, T.J. 2005. Whose culture has capital? A critical race theory discussion of community cultural wealth. Race, Ethnicity and Education 8, no. 1: 69-91. 